\title{
Literary Analysis of Figurative Symbolism in Tembang Oghem Macapat as Social Forecast Manner used by Madura Societies
}

\author{
Jaftiyatur Rohaniyah ${ }^{1}$, Samsi Rijal ${ }^{2}$ \\ English Teaching Department, FKIP, Universitas Islam Madura ${ }^{1,2}$

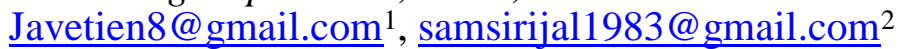

\begin{abstract}
Macapat is one of the ancient old culture existed in Madura especially in some villages in Pamekasan. This was becoming uninterested culture among society nowdays, exactly for millennial generation. Despite this, this culture is still sustained by Madura society. Macapat has a beautiful song or tembang in every steps of meaning. The manuscript contains the legend of Prophet Muhammad and his Sohabah. The manuscript of Macapat is usually used as a forecast manner in making prediction of problem solving by Madurese people in Larangan Luar Village. This is showed 'Oghem' as a part of Macapat. The song of macapat generally use figurative language and symbolism to show the hidden meaning in the manuscript. Then, it is analyzed as literary analysis in socio-cultural approach. This research used qualitative method in deep observation approach. There are two focus of research: the way of societies in doing forecast and the literary analysis of symbolism in the Song of Oghem Macapat. This research purposed to have deep understanding of Literature in Social aspect of culture. The result of the research was clearly explained and found that society belief about oghem as a way to give real contribution for their social life. While the symbolism of macapat was found as figurative symbol of situation which was implied in the song.

Keywords: Symbolism, Macapat, Oghem
\end{abstract}

\section{Introduction}

Macapat was the ancient cultural song since XIV BC. It has been a long time macapat maintained since 1964 by Madura society exactly in Dusun Bicabbih 2, Desa Larangan Luar. It was become a culture among society. The founder of macapat in this village is Bpk. Hasan and Bpk. Suratmo from Dualas (Susanto, Vol.13:209). Both of them were motivated to introduce macapat culture for young generation in Larangan Luar Village. After they were passed a way, then it has new generation namely Bpk Maskur who manage Macapat culture and it is today existed in this village.

According to Haidar (2008: 5) Tembang macapat is a Javanese literary work in the form of traditional poetry which is the work of the ancestral cultural heritage of the Indonesian people. Apart from Java, macapat-type songs are also found in other regions in Indonesia such as in Bali and in Sunda.

Macapat was conducted as annual agenda in every Thursday night in society. It was held in change from home to home which is called as "koloman macapat malem kemmisen" in Madurese language. All the member of this koloman macapat were males. It usully started at 21.00 until midnight or sometime it was finished in Subuh at the morning. Macapat was also held as ceremonial agenda in society, such as: hajatan, rokat pandhabe, wedding ceremony.

According to Oemar Sastrodiwirjo in the Pamekasan Encyclopedia (2010: 209) there are nine types of macapat known in Madura, namely: artate, dhurma, kasmaran, kenante, maskumambang, mejhil, pangkor, pujhung, senom.

In Atnawi's research (2006: 60) the term Macapat is another designation from the book 'Serat Suluk Patmoroso' written by K. Moh. Kholil, better known as Ki Anumerto Dirjo Wiwangsit in 1923. K. Moh. Kholil is a poet in Sumenep precisely in Buju 'Pellan, Sendang Village. This book is written in the form of macapat song, which consists of 4 songs, namely: 1) Senom song I, II, III. 2) Tembang Artate I, II, III, IV. 3) Durma song. 4) Tembang Kasmaran. Tembang macapat includes poetry stories that are plays. That is, from the beginning to the end of the stanza is a sequence of stories that are continued and related.

According to Susanto (2016: Vol.44) The manuscript of Macapat was written in four syllabic words. The Javanese meaning of Macapat is "maca papat-papat" where the meaning is "membaca empat per empat". 


\section{VOL. 02 NO. 01, JUNE 2020}

In every couplet of the song (Tembang) in Macapat were existed line of sentences which was usually called as gatra, and every gatra have certain syllabic words. The song of Macapat was usually held as routine program in every Wednesday night by society in this village. Macapat was often used as a traditional song before sleep. It was often used by old-society in every nigh as sound asleep for their children. Its not only for that case, Macapat also has social function among societies in Larangan Luar village. Aside from being entertainment, this song is also functioned as a wedding activities ceremony, circumcision ceremony, as well as the ritual ceremony. In fact, local people believe that the song of mamaca / macapat also serves as a means of solving social problems in the philosophy of the life cycle called 'nyangkhe oghem' . Oghem is a prediction to guess a part of a person's way of life which is done traditionally.

In this nyangkhe 'oghem session, many symbolism speech were obtained from the macapat manuscript to predict a solution to the problem intended. In this case, panèghès often uses figurative language especially symbolism in explaining the contents of texts read by pamaos to predict a solution to the problems of society. So it is important that researchers take the figurative domain of language as a literary study in macapat song. In this case, researchers want to raise the formulation of the problem to examine more deeply about this research, including: The way of societies in doing forecast and the literary analysis of symbolism in the Song of Oghem Macapat. According to Dancygier (2014: 1) Language configuration is a figurative theory commonly used in literary works to show an aesthetic value contained in certain texts and poetry texts, as mentioned in his book 'figurative language' says:

"... Figurative language was thought of as being one aspect of what

gives a text - in particular, a poetic text - special esthetic value..."

However, in general, researchers describe figurative language as the language used by poets to say things in an unusual way, which is indirectly to express their meaning. Figurative language consists of decorations that give rise to the meaning of class and symbols that give rise to the meaning of symbols.

Symbols are commonly used by poets in clarifying meaning and making the tone and atmosphere of poetry more clear, so that it can arouse the hearts of readers. Mining in poetry is considered important because according to some poets the words of daily life are not enough to express the meaning that is to be conveyed to reader

In addition, symbols and figures of speech contribute to the suggestion. Symbols are divided into several types, namely: 1) Color symbols: colors have certain character characteristics to express the feelings of the poet. 2) Object symbol: This symbolization is done by using the name of the object to replace something that the poet wants to say. 3). Sound symbol: the sound created by the poet symbolizes a certain feeling to create a special atmosphere in a poem. The use of the sound symbol is very closely related to the rhyme and diction in poetry. 4) Symbol of atmosphere: an atmosphere and not just a cursory event.

\section{METHODS}

In this study the method used is a qualitative method (qualitative approach), which in this method requires a strong and deep analysis. This is mentioned in his book Bogdan and Biklen (2007: 2) states that in this qualitative approach the characteristics of the method used are deep observation and depth interviews as the main data collection instrument. In this research, data collection methods used are in-depth interviews, observation and script documentation study.

\section{FINDINGS AND DISCUSSION}

The results of this study were presented on the results of 2 times direct observations made by researchers in following the macapat / mamaca event in which there was a nyangkhe 'oghem session, in which the event was attended by a group of society in Bicabbi 2, Larangan Luar Village, Kec. Larangan. From these 3 times direct observation, researchers found 4 oghem predictions. Below is the contents of the oghem that was brought up by Pamaos and Paneghes based on the intentions of the community when the macapat event took place and will be lifted into a data in this study.

\section{How was the way of societies in doing forecast and the literary analysis of symbolism in the Song of Oghem}

As researchers have done for $3 \mathrm{x}$ observations in the field, it was found that, people often do oghem forecasting in macapat song, this is done as a form of effort and community effort in preparing or resolving social problems. The method used by the community in nyangkhe 'oghem are; society must have the intention or issue that will be predicted in oghem, after having the 
intention and issue, then society attend and participate in mamaca / macapat events held, after the nyangghe 'oghem session is developed, then people who wants to predict the problem Give money (without nominal limit) to be put on a song sheet which will later be read by Pamaos and Paneghes, as shown in the documentation below:

Picture 1: oghem contract between people and pamaos in nyangghe'oghem

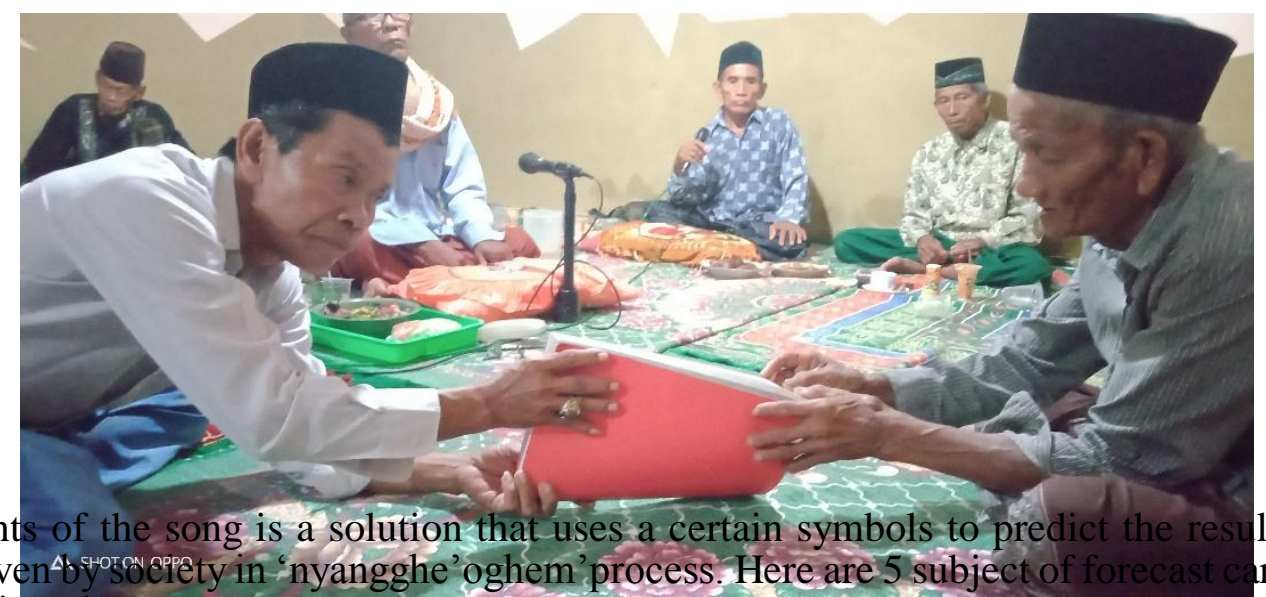

The contents of the song is a solution that uses a certain symbols to predict the result of the
forecast given 4 byosogepety in 'nyangghe' oghem'process. Here are 5 subject of forecast carried out by society in oghem:

1. $\quad 1^{\text {st }}$ Data taken from P. Mukti forecast

\begin{tabular}{|c|c|c|c|}
\hline Subject & Song of Oghem & Content of Song & Oghem Prediction \\
\hline $\begin{array}{l}\text { Mukti predicted his } \\
\text { child could go to his } \\
\text { own house and not } \\
\text { live in his in-law's } \\
\text { house. Could the } \\
\text { child go home } \\
\text { someday? Or instead } \\
\text { stay at home in-law's } \\
\text { house? }\end{array}$ & Kasmaran & $\begin{array}{l}\text { Dibudinah ekotep. } \\
\text { Bileh ekotep pas } \\
\text { remmok ancor ben } \\
\text { langtolangah.Oreng } \\
\text { pasar pas acerreng } \\
\text { bettalebet.. Ambek } \\
\text { engkok manok..kok } \\
\text { noroah asolat manok.. } \\
\text { Sengkok asolat } \\
\text { mongku kakbatullah } \\
\text { arowa manok" }\end{array}$ & $\begin{array}{l}\text { There is hope of } \\
\text { success, however, } \\
\text { there is still a } \\
\text { surprising event at } \\
\text { the beginning, the } \\
\text { problem is created by } \\
\text { outsiders (not the } \\
\text { family structure } \\
\text { itself) which tends to } \\
\text { create a fuss and } \\
\text { strife against a } \\
\text { family. }\end{array}$ \\
\hline
\end{tabular}

Symbol of the song:

These contents of the song above are included in the type of language symbolization which is included in symbolizing the situation. The sentence of "Bileh ekotep pas remmok ancor ben langtolangah. Oreng pasar pas acerreng bettalebet". It symbolized a tense atmosphere and reflects physical destruction. Whereas in the sentence "Ambek engkok manok..kok noroah asolat manok .. Sengkok asolat mongku kakbatullah arowa manok" This sentence symbolizes the symbol of a good atmosphere at the end of the story. So that from the reflection of this mining, Paneghes tells the results of the forecast based on the situation contained in the song oghem, where the contents of what is predicted are reflecting the good expectations.

2. $\quad 2^{\text {nd }}$ Data taken from Ibu. Asma forecast

\begin{tabular}{|l|l|l|l|}
\hline Subject & Song of Oghem & Content of Song & Oghem Prediction \\
\hline $\begin{array}{l}\text { Is there hope for } \\
\text { recovery for the }\end{array}$ & Durma & $\begin{array}{l}\text { Bede ondem pote } \\
\text { anaungih ka nakkanak }\end{array}$ & $\begin{array}{l}\text { still able to recover } \\
\text { but only for a } \\
\text { illness in which it is } \\
\text { suffering because it is } \\
\text { very difficult to have } \\
\text { hope for recovery }\end{array}$ \\
$\begin{array}{l}\text { gentheng. continue to } \\
\text { Ebektoh panekah, } \\
\text { try and let his heart to } \\
\text { kaju behen pas able to accept the } \\
\text { bempeng. Mare } \\
\text { illness that was } \\
\text { ngempeng pas ronto predestined by God. If }\end{array}$ \\
\hline
\end{tabular}




\section{Symbol of the song:}

In the sentence above it is a symbol of the situation that reflects a cloud that shades a handsome child, after that some woods begin to grow branches and flowers. But after that the flowers fall on the ground and all prostrate to the divine, Allah azza wajalla. This is as a reference from the contents of the forecast predicted by Ibu Asma who are suffering from diabetes who have long sought a cure that does not heal, then he predicted the disease "is there still a way to recover from the disease". In accordance with the contents of the song in oghem, the song symbolizes that there is hope for improvement but that is only for a moment. In the end will return to God with special sermon if sincere in sending the test from God. This is expressed from the symbol of the situation contained in the sentence

3. $\quad 3^{\text {rd }}$ Data taken from Bpk. Pupah forecast

\begin{tabular}{|c|c|c|c|}
\hline Subject & Song of Oghem & Content of Song & Oghem Prediction \\
\hline $\begin{array}{l}\text { Is there any hope of } \\
\text { recovering the disease } \\
\text { he has and whether } \\
\text { the illness he suffered } \\
\text { is a type of illness / } \\
\text { magic, or medical } \\
\text { illness? }\end{array}$ & Pangkor & $\begin{array}{l}\text { Kusteh beden kauleh, } \\
\text { Muhammad nabi } \\
\text { kauleh..tak piteh } \\
\text { sareng malateh se } \\
\text { mekkar beunah. } \\
\text { Ropah epon nabi } \\
\text { Muhammad engki } \\
\text { kaintoh arepklirep } \\
\text { ropah epon sambih } \\
\text { ngibeh nyereppet } \\
\text { room beunah. Engki } \\
\text { panekah potenah } \\
\text { seddhe'. Kanjeng nabi } \\
\text { patot. Acellak sakone' } \\
\text { edheppeh kanjeng } \\
\text { nabi. }\end{array}$ & $\begin{array}{l}\text { It so difficult to be } \\
\text { recovered Because the } \\
\text { disease that is in his } \\
\text { body is an old disease } \\
\text { which is generally } \\
\text { happened in his body. }\end{array}$ \\
\hline
\end{tabular}

\section{Symbol of the song:}

In this 3rd oghem song is the pangkor song, which, this song is read by pamaos and paneghes to look for the results of the prophecy brought by Bpk.Pupah in predicting the disease he had long suffered, Bpk.Pupah wants to predict whether the disease that he has suffered for a long time is included in the category of syaiton (magic) or natural medical illness?

When viewed from the contents of the song, then there is a figurative meaning which belongs to the part of the metaphor which in the sentence of "Muhammad nabi kauleh ... tak piteh sareng malateh se mekkar beunah" reflects a figure of the Prophet Muhammad which is likened to fragrant jasmine which historically also mentions that this is absolutely possessed by a perfect human being namely Prophet Muhammad as a Man whom Allah privileged his life. The language configuration is not only found in the sentence, but also in the sentence of "Ropah epon nabi Muhammad engki kaintoh arepklirep ropah epon sambih ngibeh nyereppet room beunah. Engki panekah potenah seddhe'. Kanjeng nabi patot'. In this sentence, the language configuration contained is symbolism. This sentence reflects a symbol of color, shape and atmosphere that is reflected to provide a symbol of beauty for the figure of the Prophet Muhammad. From the results of this figuration, Paneghes then adorned the results of the prediction that the long-suffering illness was absolute and indeed was supposed to exist in itself, the "old disease". The results of these predictions made as a solution to the anxiety.

4. $\quad 4^{\text {th }}$ Data taken from Ibu Munipah forecast

\begin{tabular}{|l|l|l|l|}
\hline Subject & Song of Oghem & Content of Song & Oghem Prediction \\
\hline His grandson plans to & Senom & Elmoh sareng & It's better to be patient \\
\hline
\end{tabular}




\begin{tabular}{|c|c|c|}
\hline $\begin{array}{l}\text { go to Malaysia to } \\
\text { work and leave his } \\
\text { profession as a teacher } \\
\text { in Madrasas. Are there } \\
\text { any instructions in } \\
\text { choosing these two } \\
\text { things? }\end{array}$ & $\begin{array}{l}\text { aghema Kanjeng } \\
\text { nabi paneka kadhi } \\
\text { ondih, etaremah deri } \\
\text { settong oreng, ebeki } \\
\text { ka se lain/ ebilin. } \\
\text { Ebektoh ngabes dek } \\
\text { perenah nabi panekah, } \\
\text { nyonar, asabeb } \\
\text { elmonah. Nabi } \\
\text { Muhammad pade } \\
\text { ben areh }\end{array}$ & $\begin{array}{l}\text { being a teacher. Who } \\
\text { transmits a lot of } \\
\text { knowledge to the } \\
\text { Ummah. God willing, } \\
\text { finally perfect and get } \\
\text { a way out in fulfilling } \\
\text { the needs }\end{array}$ \\
\hline
\end{tabular}

\section{Symbol of the song:}

The contents of the song above reflects comparison or what is commonly referred to as simile in the figurative language. The comparison sentence is marked by the use of conjunctions such as, like, like, as a function in providing a comparison of an object or nature. So, in this sentence "..elmoh sareng aghema Kanjeng nabi paneka kadhi ondih" the use of the word 'kadhi' which means 'like' in English, becomes a sign of comparison, namely comparing a science and religion of the Prophet with a sacred object in which the Madurese people used to call it 'ondhi'. This object is hereditary in existence. So, from the results of this figure, Oghem song suggests that teaching a science and religion is a very noble thing because science is a charity that never runs out of benefits and rewards. This then becomes an answer from Ibu Munipah forecast. She is concerned about her grandchildren who wish to migrate to Malaysia and leave her profession as a teacher in a small Madrasah. Ibu. Munipah asked about what would be better for her grandchildren between going abroad or staying at home with a small income that was only a madrasa teacher.

\section{Conclusion}

From the fact and data which are gotten in observation above, the researcher concluded that oghem was generally use as symbol of solution as prediction in solving the doubt, enxaity, and other social problems. While figurative language and symbolism used as a key in translating the meaning of the song into prediction result for the Subject carried out in the oghem it self.

\section{References:}

Edi Susanto, Tembhang Macapat Madura: Perspektif Sosiologi Pengetahuan” Jurnal Nuansa, Vol.13, No.1, Desember 2016

Puji Santosa, Community Social Function of Macapat, Research Gate, Vol.44, Desember 2016

Zahra Haidar, Macapat: Tembang Jawa Indah dan Kaya Makna) Jakarta: Kemendikbud Press, 2018

Tim Penyusun, Ensiklopedi Pamekasan, Yogyakarta: PT Intan Sejati, 2010

Barbara Dancygier, Eve Sweetser, Figurative Language, Newyork: Cambridge University Press, 2014

Herbert L. Colston, Using Figurative Language, New York, Cambridge University Press, 2015

Bogdan, Robert C, dan Knoop Biklen, Qualitative Research for Education: An Introduction to Theory and Methods, Boston: Allyn and Bacon, 2007 